\title{
ENVIRONMENTALLY-FRIENDLY PREPARATION OF CHITOSAN MICROSPHERES AND ENCAPSULATION STUDIES OF CINNAMALDEHYDE: A CONVENIENT SUSTAINED RELEASE SYSTEM FOR CINNAMALDEHYDE
}

\author{
Elif Karacan Yeldir, Ayhan Oral \\ Çanakkale Onsekiz Mart University, Faculty of Arts and Sciences, Chemistry Department, \\ Çanakkale, Turkey \\ elifkaracan@comu.edu.tr, ayhanoral@comu.edu.tr
}

\begin{abstract}
Chitosan, a biodegradable and biocompatible polysaccharide, is a biopolymer with high potential for biomedical applications. In the scope of this study, chitosan microcapsules were prepared via a green method, without using any surfactants or crosslinkers. Cinnamaldehyde encapsulated microspheres were obtained by the same method and characterized by FTIR spectroscopy, XRD spectroscopy, and SEM. The release study of encapsulated cinnamaldehyde was carried out in a $\mathrm{pH} 7.4$ phosphate buffered saline (PBS) at $37{ }^{\circ} \mathrm{C}$. The amount of cinnamaldehyde released was analyzed using UV-Vis spectroscopy and GC/MS-MS. Accordingly, it was found that $350 \mathrm{mg}$ of cinnamaldehyde was encapsulated per gram of chitosan, and the maximum amount of cinnamaldehyde released into the PBS medium was about 8 ppm. In addition, the release was seen to continue when the buffer was renewed. It is thought that the obtained cinnamaldehyde encapsulated chitosan microspheres could be used as a sustained release system.
\end{abstract}

Keywords: chitosan; cinnamaldehyde; sustained release; microspheres

\section{ЕКОЛОШКА ПОДГОТОВКА НА МИКРОСФЕРИ ОД ХИТОЗАН И СТУДИИ НА ЕНКАПСУЛАЦИЈА НА ЦИНАМАЛДЕХИД: ПОГОДЕН ОДРЖЛИВ СИСТЕМ НА ОСЛОБДУВАЊЕ НА ЦИНАМАЛДЕХИД}

\begin{abstract}
Хитозан, биоразградлив и биокомпатибилен полисахарид, е биополимер со висок потенцијал за биохемиска примена. Во рамките на оваа студија беа подготвени микрокапсули на хитозан според еколошки метод, без употреба на површински активни супстанции или вмрежувачи. Беа добиени енкапсулирани микросфери на цинамалдехид според истиот метод и беа карактеризирани со FTIR спектроскопија, XRD спектроскопија и SEM. Ослобдувањето на енкалпуслираниот цинамалдехид беше проучено на $\mathrm{pH}$ 7,0 во сол на фосфатен пуфер (PBS) на 37 ${ }^{\circ} \mathrm{C}$. Количината на ослободениот цинамалдехид беше анализирана со примена на UV-Vis спектроскопија и GC/MS-MS. Најдено е дека $350 \mathrm{mg}$ е енкапуслиран на грам хитозан и максималното количество ослободен во PBS медиумот е околу 8 ppm. Покрај тоа, забележано е дека ослободувањето продолжува при обновување на пуферот. Се смета дека енкапуслиран цинамалдехид во микросфери од хитозан може да се користат како одржлив систем за ослободување.
\end{abstract}

Клучни зборови: хитозан; цинамалдехид; одржливо ослободување; микорсфери

\section{INTRODUCTION}

Chitosan (CS) is a biodegradable and biocompatible linear polysaccharide that is derived from alkaline deacetylation of chitin, which is the second most abundant natural polymer after cellulose (Fig. 1) [1]. It is a renewable resource and an inexpensive material [2]. The molecular weight of CS spans a very broad range, from 300 to over $1000 \mathrm{kDa}$, depending on its source and the prepa- 
ration procedure [3]. Due to its non-toxicity, antimicrobial properties and solubility in water, CS is a good candidate, especially for biomedical applications [4-9]. The properties of CS are also tunable by chemical modification, due to its functional groups [10-12]. Furthermore, CS is the only biodegradable polymers with a cationic character.
These properties make CS unique for delivery systems [13, 14]. Studies show that CS is used for oral, nasal, ocular, vaginal, buccal, parenteral, and intravesical drug delivery systems. Additionally, according to recent studies, it is a very promising system for vaccine delivery [13].

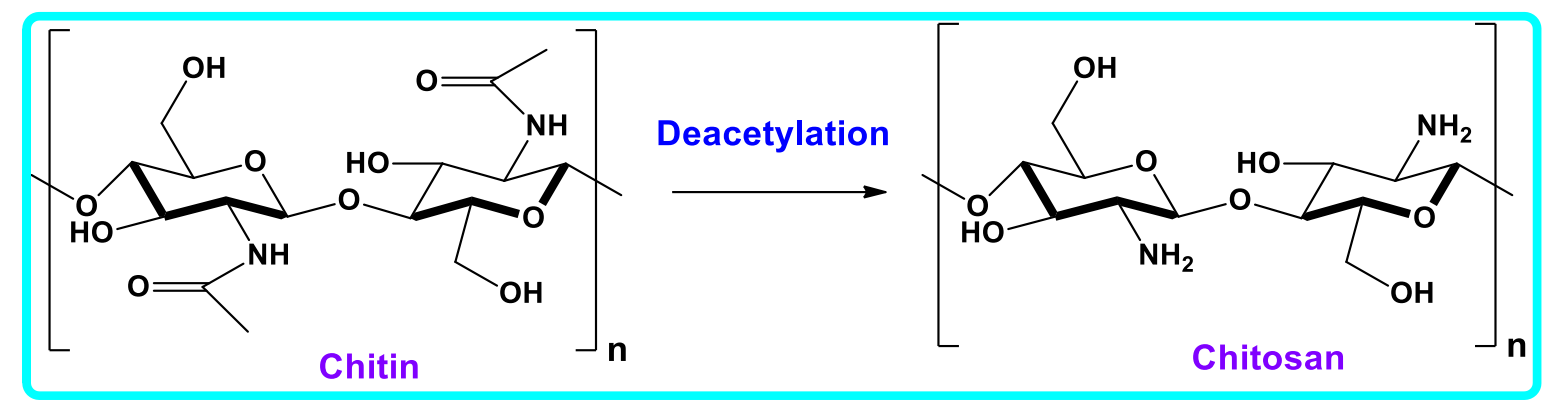

Fig. 1. Structures of chitin and chitosan (CS)

Essential oils extracted from plants or spices are volatile and aromatic liquids, and they include a number of biologically active compounds, such as phenolic compounds (phenyl propanoids) and/or terpenoids [15]. Recent studies show that these phytochemicals are more often used in pharmaceuticals, food, or cosmetics than synthetic materials [16]. However, they evaporate and are sensitive to light, heat or air [17]. Encapsulation techniques are commonly used to prevent the disadvantages of essential oils [15, 17]. Cinnamaldehyde (CIN), which is derived from cinnamon bark, is one of these phytochemicals (Figure 2). CIN is a broad spectrum antibacterial and is also known to be effective against the most common bacteria, such as Escherichia coli, Salmonella, and Staphylococcus aureus, and inhibit the production of microbial secondary metabolites [18]. It inhibits $P$. aerugino$s a$ activity at a minimum inhibitory concentration (MIC) of $300 \mathrm{mg} / \mathrm{ml}$ [19]. CIN has been approved by the FDA to be safe for use due to its antibacterial and antifungal effects [20].

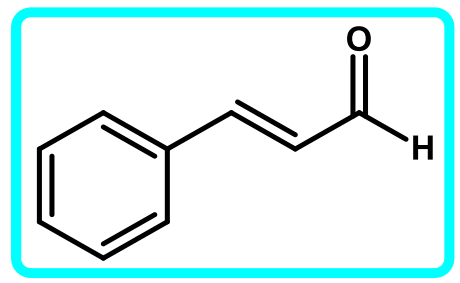

Fig. 2. Structure of cinnamaldehyde (CIN)

Although the encapsulation of CIN in a polymeric system has been studied with many natural (liposomes, polylactic acid (PLA), gelatin, starch, etc.) or synthetic polymers, there are no studies reported in the literature without a crosslinking or surfactant substance within the CS matrix $[16,19$, 21-23]. In this study, CS was prepared, CIN was encapsulated in CS microbeads using a green method, and the in vitro release of CIN was investigated from the microbeads. No crosslinking agent was used, which could be an advantage for the use of this material in tissue engineering and food packaging applications.

\section{EXPERIMENTAL SECTION}

\subsection{Materials}

CS (molecular weight 100000-300000 kDa) was purchased from Acros Organics. CIN (natural, $\geq 95 \%), \mathrm{NaOH}$ pellets, and acetic acid (glacial, $100 \%$ ) were supplied by Merck. $\mathrm{NaCl}, \mathrm{KCl}$, $\mathrm{Na}_{2} \mathrm{HPO}_{4}$, and $\mathrm{KH}_{2} \mathrm{PO}_{4}$ chemicals, required to prepare the PBS, were supplied by Merck, and all are ACS reagent $(\geq 98 \%)$ grade. All chemicals were used as received. Microbeads were obtained with an insulin syringe ( $0.4 \mathrm{~mm}$ in diameter).

\subsection{Characterization}

The infrared spectra of bare and CIN encapsulated microbeads were recorded with a Perkin Elmer Spectrum One FTIR system, using the ATR sampling accessory. After the CS-CIN microspheres were obtained, they were dried in a vacuum oven at low temperature, and FTIR analysis was performed. A Perkin Elmer Lambda 25 UV- 
Vis Spectrophotometer was used for CIN qualitative analysis. The spectra were obtained using a 3to-1 volumetric mixture of methanol and PBS as the solvent system, in the wavelength range of 200-400 nm. The second method used for the quantitative analysis of CIN was GC/MS-MS (Thermo Finnigan Trace Ultra GC) with a $30 \mathrm{~m}$ 5MS-GC fused silica capillary column. The x-ray diffraction (XRD) pattern of the materials was recorded using a Panalytical Empyrean X-ray diffractometer with $\mathrm{Cu} \mathrm{K} \alpha$ radiation $\left(\lambda=1.5406 \mathrm{~A}^{\circ}, 45\right.$ $\mathrm{kV}, 40 \mathrm{~mA})$. The surface properties of the obtained microspheres were analyzed with scanning electron microscopy (SEM) (JEOL SEM-7100-EDX).

\subsection{Methods}

\subsubsection{Preparation of CS beads}

A $3.5 \%$ CS solution $(\mathrm{m} / \mathrm{v})$ was prepared in $7 \%(\mathrm{v} / \mathrm{v})$ acetic acid solution and sonicated for a minute, in order to remove the air bubbles in the solution. CS microspheres were obtained by dropping the CS solution slowly into a $10 \% \mathrm{NaOH}$ solution with an insulin syringe, while being mixed at $300 \mathrm{rpm}$ [24, 25]. The microspheres were washed with distilled water to eliminate the $\mathrm{NaOH}$ remaining on the surface and were preserved in $\mathrm{pH}$ 7.4 PBS.

\subsubsection{Encapsulation of essential oils and encapsulation efficiency (EE)}

First of all, CIN was dissolved in methanol, with the amount of CIN being equivalent to $25 \%$ and $50 \%$ (by weight) of the CS used. Then, $7 \%$ acetic acid solution and $0.3 \mathrm{~g} \mathrm{CS}$ were added and mixed until a homogeneous mixture was obtained. The mixture was then degassed with an ultrasonic bath. An amount of CIN equivalent to $50 \%$ of the used CS was found to be the highest amount that could be dissolved in the methanol:PBS (3:1) system, i.e. CIN with a higher concentration could not be used in this encapsulation system. Hence, $25 \%$ and $50 \%$ CS-CIN microspheres were obtained by dropping this solution into $10 \%(\mathrm{~m} / \mathrm{v}) \mathrm{NaOH}$ solution with an insulin syringe. The microspheres were then washed with distilled water to remove $\mathrm{NaOH}$ residue on the surface of the microspheres (Fig. 3).

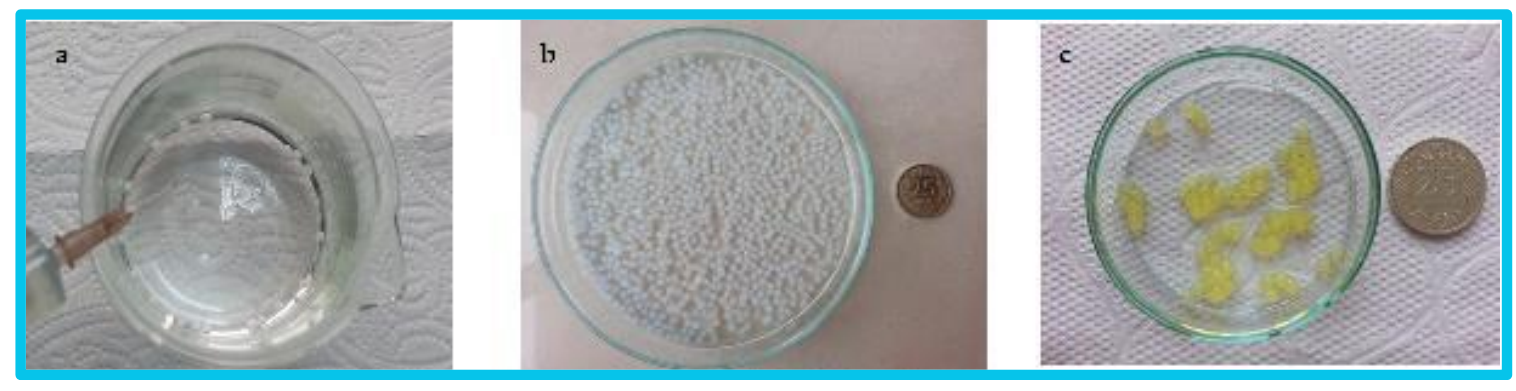

Fig. 3. a) Preparation of microspheres, b) CS microspheres, and c) CS-CIN microspheres

The ratio of the amount of CIN encapsulated in the CS microspheres to the amount of CIN put into the medium gives the encapsulation efficiency (EE). Thus, knowing the \%EE explained how much CIN the microspheres would encapsulate. To calculate the amount of encapsulated CIN, $25 \%$ and $50 \%$ CS-CIN microspheres, prepared by dropping into the $\mathrm{NaOH}$ solution, were removed from the medium, and the remaining solution was diluted with methanol such that the ratio of methanol:PBS was 3:1. The amount of non-encapsulated CIN was determined by UV-VIS Spectrophotometry at $287 \mathrm{~nm}$ using the calibration curve of CIN $\left(y=28861 x-0.014, \mathrm{R}^{2}=0.9957\right)$. The EE was calculated using equation(1) [26]:

\footnotetext{
Encapsulation Efficiency (\%) =

$=\frac{(\text { Total CIN amount }- \text { non encapsulated CIN amount })}{\text { Totat CIN amount }} \times 100$
}

\subsubsection{Study on the in vitro Release of Natural Antibacterial Substance from CS Microspheres}

The release of CIN from CS-CIN microspheres was carried out by small changes made in previously reported studies $[27,28]$. Phosphate buffer (PBS) was used at $37{ }^{\circ} \mathrm{C}$ to perform the study on the release of CIN from $25 \%$ and $50 \%$ CS-CIN microspheres. Samples were also taken periodically while all of the CS microspheres prepared from $0.3 \mathrm{~g}$ CS within $50 \mathrm{ml}$ PBS solution were being mixed for 5 days at $400 \mathrm{rpm}$. These samples were analyzed using UV-Vis spectrophotometry and GC-MS/MS. The UV-Vis spectra of CIN and samples in the methanol:PBS (3:1) solvent system were recorded in quartz cells in the wavelength range of $200-400 \mathrm{~nm}$. A 5MS-GC fused silica capillary column $(30 \mathrm{~m} 0.25 \mathrm{~mm}$, i.d. $0.25 \mu \mathrm{m}$ film thickness) was used in GC-MS anal- 
ysis, and a $2.00 \mu \mathrm{l}$ sample was injected onto the column. Helium and nitrogen were used as carrier gas. The temperature of the injector was $200{ }^{\circ} \mathrm{C}$.

With the help of the data obtained as a result of the analysis, the cumulative percentage of CIN released from the microspheres was calculated. According to equation 2, the percentage of the cumulative amount of CIN released was calculated from the ratio of the amount of CIN released in the sample taken over time to the maximum amount of CIN released [15, 28].

$$
\begin{gathered}
\text { Cumulative release percentage }= \\
=\sum_{t=0}^{t} \frac{M t}{M 0} \times 100
\end{gathered}
$$

In the second part of the release study, all the solvent for release was removed after stirring at 37 ${ }^{\circ} \mathrm{C}$ for 1 hour, new solvent was placed on the CS microspheres, and the stirring was continued under the same conditions. This procedure was repeated until the amount of CIN decreased in the solution.

\section{RESULTS AND DISCUSSION}

\subsection{UV-Vis and FTIR analysis}

Studies have shown that the solubility of CIN in water is $1.1 \mathrm{~g} / \mathrm{l}$ at $20{ }^{\circ} \mathrm{C}$, and it dissolves completely in organic solvents [29]. Methanol is one of the preferred materials in the solvent system, since it is miscible with water and the essential oil, and it can be easily removed from the media. The optimization study investigated the lowest amount of methanol that could be used to dissolve the most CIN. The ratio of methanol:PBS was found to be $3: 1$, which is the minimum amount of methanol for CIN solubility.

The UV spectra of CIN was taken in methanol:PBS (3:1) solution in the range of $200-400 \mathrm{~nm}$. One maximum absorption peak is seen for CIN, belonging to the electronic transition at $287 \mathrm{~nm} n$ $\rightarrow \pi^{*}$, caused by the conjugation of the molecule [30] (Fig. 4).

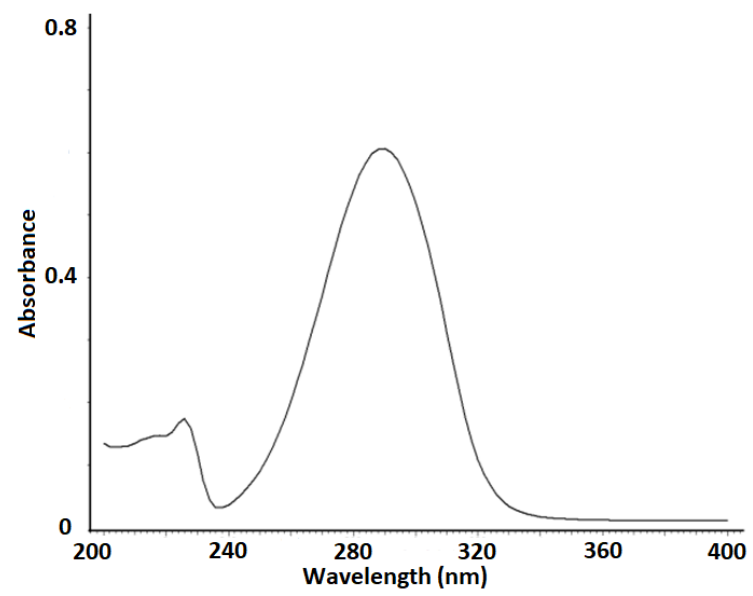

Fig. 4. UV-Vis spectra of CIN $\left(2 \times 10^{-5} \mathrm{M}\right.$ in methanol:PBS 3:1)

The FTIR spectra of CS, CIN, and $50 \%$ CSCIN microspheres are shown in Figure 5. The stretching vibration of the $-\mathrm{NH}_{2}$ and $-\mathrm{OH}$ groups of CS are observed at $3100-3600 \mathrm{~cm}^{-1}$ as a broad band [31]. Unlike the bare CS microspheres, the peak at $1690 \mathrm{~cm}^{-1}$ corresponds to the $\mathrm{C}=\mathrm{O}$ stretching of CIN, and phenyl groups are observed at 1580 and 1440 $\mathrm{cm}^{-1}$ in the $50 \% \mathrm{CS}-\mathrm{CIN}$ microsphere spectra.

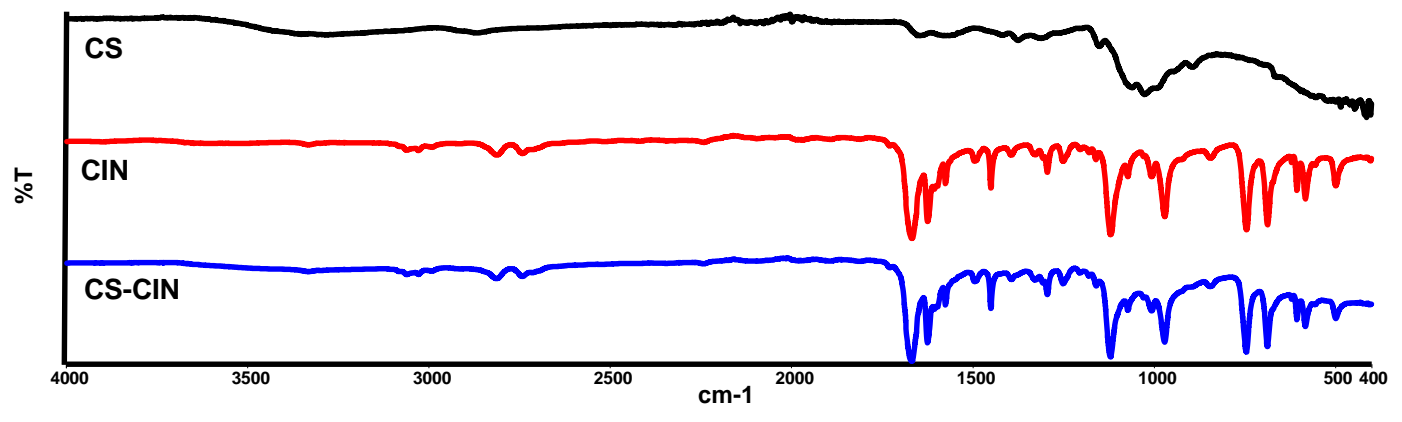

Fig. 5. CS, CIN, and CS-CIN microsphere FTIR spectra

\subsection{XRD analysis}

The XRD of powdered CS, bare CS microspheres, and $50 \%$ CS-CIN microspheres are given in Figure 6. The characteristic peak of the crystalline structure of $\mathrm{CS}$ is observed at $2 \Theta=20^{\circ}$ [31, 32]. However, the peak intensity of the powder form of CS is greater than the microsphere form. This is attributed to the fact that the microspheres are more amorphous. Previous studies have shown that morphological changes decrease the crystallinity of the powdered CS [31]. Also, the crystallinity of the CS microspheres is slightly increased by the addition of CIN. 


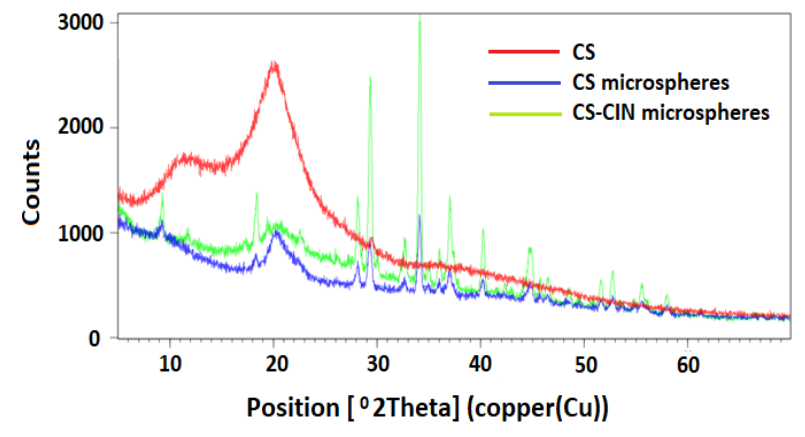

Fig. 6. X-ray diffractograms of CS powder, CS microspheres, and CS-CIN microspheres
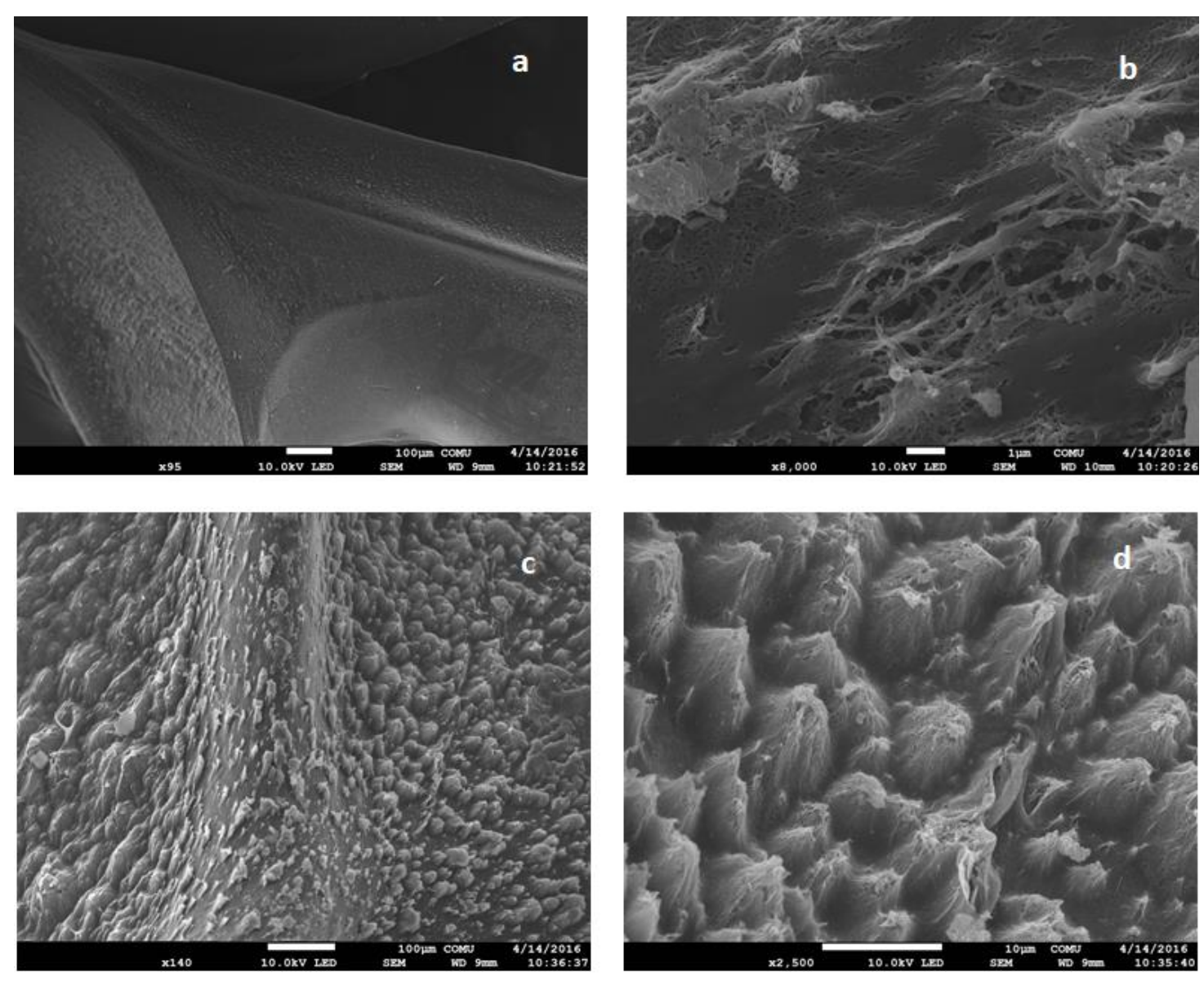

Fig. 7. SEM images of a) and b) CS microspheres, and c) and d) CS-CIN microspheres

\subsection{In vitro release of CIN from CS-CIN microspheres}

CS-CIN solutions were prepared by adding CIN in an amount equivalent to $25 \%$ and $50 \%$ of the CS amount (by weight), and the $25 \%$ and $50 \%$ CS-CIN microspheres were prepared by dropping the solution into $\mathrm{NaOH}$. The amount of CIN released from the CS-CIN microspheres was determined by both UV-Vis spectrophotometry and GCMS. The results obtained with both methods were observed to be compatible with each other.

\subsection{Morphological analysis}

The morphology of CS and CS-CIN microspheres was investigated by SEM after the beads were freeze dried. According to the SEM images given in Figure 7, the surface of the CS microspheres look smooth (Figs. 7a and 7b). However, the surface of the CS-CIN microspheres appear rough. This is thought to be due to the heterogeneous mixing of CIN with CS and, thanks to this heterogeneous structure, it can be said that CIN aggregates in the form of small peaks on the CS microspheres (Figs. 7c and 7d).

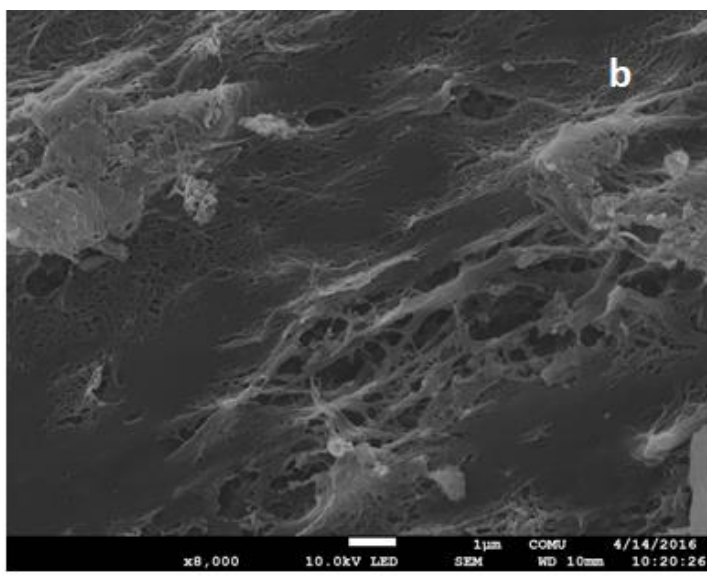

The results of UV-Vis spectrophotometric analysis showed that the amount of CIN released from the $50 \%$ CS-CIN microspheres reached 7.93 $( \pm 0.08) \mathrm{ppm}$, the maximum amount, in PBS buffer at $37{ }^{\circ} \mathrm{C}$ after approximately 60 minutes (Fig. 8), and the results of GC/MS-MS analysis indicated that the maximum amount of CIN released reached $8.01( \pm 0.06) \mathrm{ppm}$. Moreover, the obtained CS-CIN microspheres were found to contain $350.06( \pm 0.13)$ mg CIN per $1.00 \mathrm{~g} \mathrm{CS}$. 

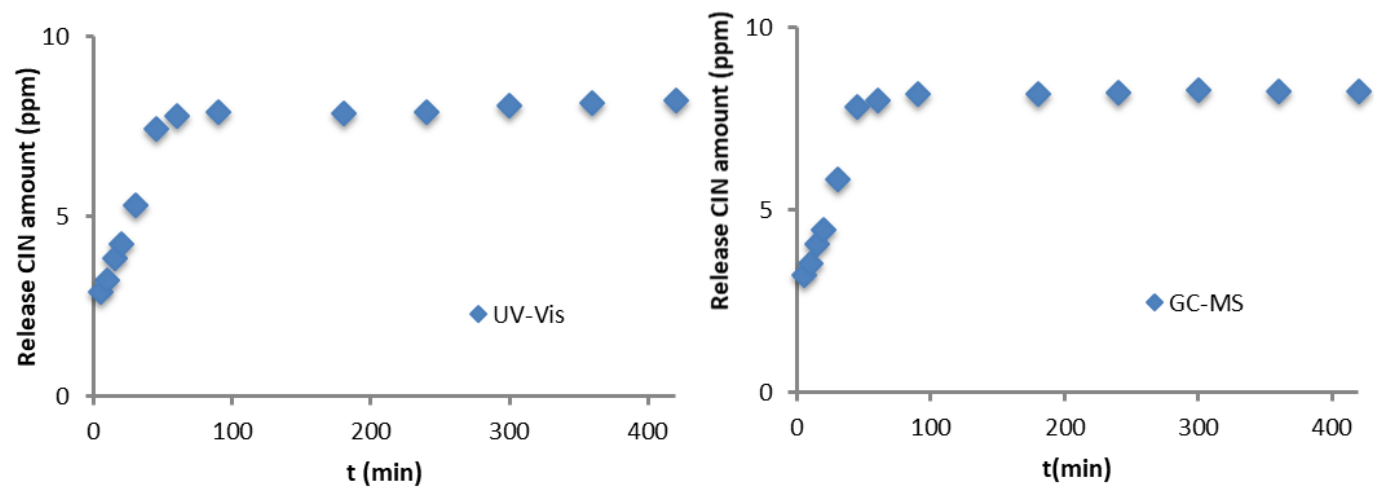

Fig. 8. Graphical representation of the amount of released CIN obtained by UV-Vis spectrophotometric and GC/MS-MS analyses

From the UV-Vis spectrophotometric analysis, it was found that $25 \%$ CS-CIN microspheres encapsulated $184.24( \pm 0.21) \mathrm{mg}$ CIN per $1 \mathrm{~g}$ of CS, while the $50 \%$ CS-CIN microspheres encapsulated $350.06( \pm 0.13) \mathrm{mg}$ CIN per $1 \mathrm{~g}$ of CS. Furthermore, both the $25 \%$ CS-CIN microspheres and the $50 \%$ CS-CIN microspheres appeared to release the maximum amount of CIN after 60 minutes at $37^{\circ} \mathrm{C}$ in $\mathrm{pH} 7.4 \mathrm{PBS}$ solution. Accordingly, the maximum amount of CIN released from $25 \%$ CSCIN microspheres was $6.17( \pm 0.10) \mathrm{ppm}$ (Figure 9). The EE (\%) of the $25 \%$ and $50 \%$ CS-CIN microspheres, calculated from the spectrophotometric measurements using the CIN calibration curve, was found to be $73.60 \%( \pm 2.11)$ and $70.43 \%$ $( \pm 1.65)$, respectively. Although the encapsulation of CIN in CS microspheres has not been studied before, the EE (\%) results of different essential oils encapsulated in CS microspheres have been observed to be less than $70.43 \%$ [33]. CIN encapsulated in CS nanoparticles were prepared in earlier studies, and the EE (\%) of these system were very close to the results in this work where microspheres were used [26, 34, 35].

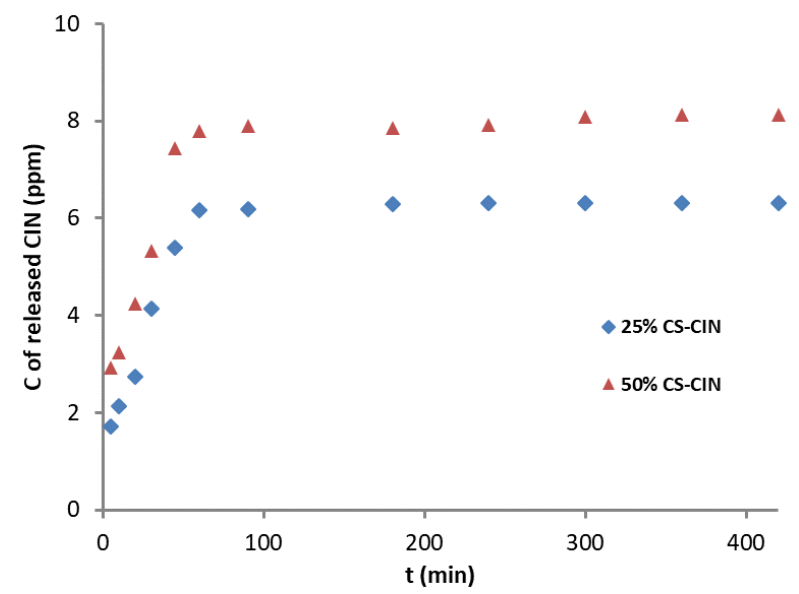

Fig. 9. Concentration of released CIN for the $25 \%$ and $50 \%$ CIN-CS microspheres
The graph of CIN cumulative percentage versus time is shown in Figure 10. According to this graph, the released amount of CIN was $7.10 \%$ after 60 minutes for $25 \%$ CS-CIN microspheres and $7.42 \%$ for $50 \%$ CS-CIN microspheres. It was obvious that the cumulative percentages of released CIN from the $50 \%$ and $25 \%$ CS-CIN microspheres were very close to each other. Therefore, it can be estimated/predicted that the maximum amount released from CS microspheres obtained by this encapsulation method in the first 60 minutes will be about $7.5 \%$ of the encapsulated amount.

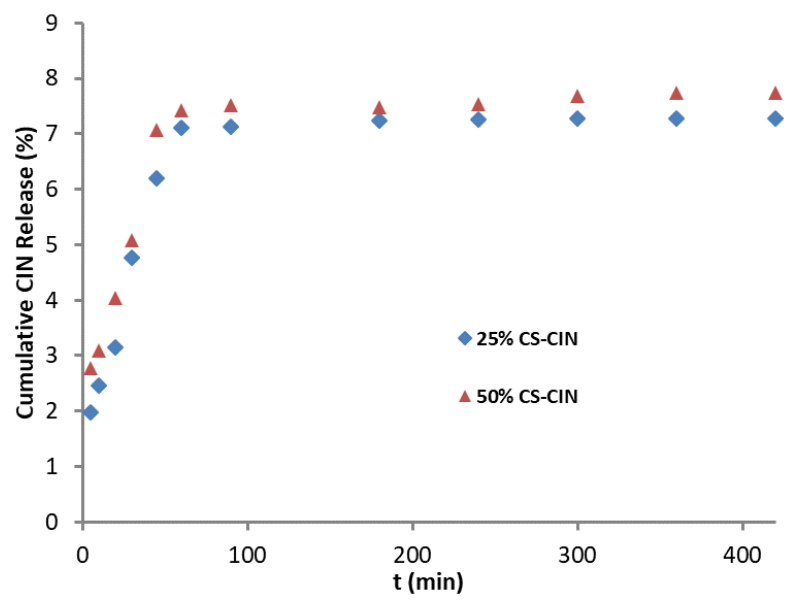

Fig. 10. Percentage of cumulative CIN released from $25 \%$ and $50 \%$ CIN-CS microspheres

After 60 minutes, the maximum amount of released CIN was $6.17 \mathrm{ppm}$ for $25 \% \mathrm{CIN}-\mathrm{CS}$ and $8.01 \mathrm{ppm}$ for $50 \%$ CS-CIN microspheres but, per gram, CS can encapsulate $184.24 \mathrm{mg}$ CIN for $25 \%$ CS-CIN microspheres and $350.06 \mathrm{mg}$ CIN for 50 $\%$ CS-CIN microspheres, according to the UV-Vis results. Therefore, all PBS was removed from the CS-CIN microspheres after 60 minutes, and fresh PBS at $37{ }^{\circ} \mathrm{C}$ was added. When the sample was 
examined by UV-Vis spectrophotometry, CIN release was seen to continue, and this process was repeated until the amount of CIN in the solution decreased, as shown in Figure 11.

The maximum amount of CIN increased from $6.17( \pm 0.10) \mathrm{ppm}$ in the first cycle to 6.63 $( \pm 0.19) \mathrm{ppm}$ in the second sample for $25 \% \mathrm{CS}$ CIN microspheres and from $7.93( \pm 0.08) \mathrm{ppm}$ in the first cycle to $8.67( \pm 0.15) \mathrm{ppm}$ in the second sample for $50 \%$ CS-CIN microspheres. The amount of CIN released from the $25 \%$ CS-CIN microspheres reached $7.27( \pm 0.11) \mathrm{ppm}$ in the third cycle and then began to diminish, to $7.25( \pm 0.12)$ $\mathrm{ppm}$ in $4^{\text {th }}, 6.83( \pm 0.10) \mathrm{ppm}$ in the $5^{\text {th }}, 6.05$ $( \pm 0.09) \mathrm{ppm}$ in the $6^{\text {th }}, 5.25( \pm 0.12)$ in the $7^{\text {th }}, 4.11$ $( \pm 0.13) \mathrm{ppm}$ in the $8^{\text {th }}$, and $3.02( \pm 0.09) \mathrm{ppm}$ in the $9^{\text {th }}$ cycle. The amount of CIN released from the 50 $\%$ CS-CIN microspheres reached $13.76( \pm 0.18)$ ppm in the $4^{\text {th }}$ cycle and then began to decrease: in the $9^{\text {th }}$ cycle, the amount of CIN diminished to 5.42 $( \pm 0.02) \mathrm{ppm}$, falling below the amount of the first cycle. After 9 cycles, it was found that $95.09 \%$ of total encapsulated CIN was released from the $25 \%$ CS-CIN microspheres and $89.02 \%$ from the $50 \%$ CS-CIN microspheres. The importance of this part of the study is that it proves that these microspheres can be used for systems where the environment of the released solution is constantly changing, for example, in blood.

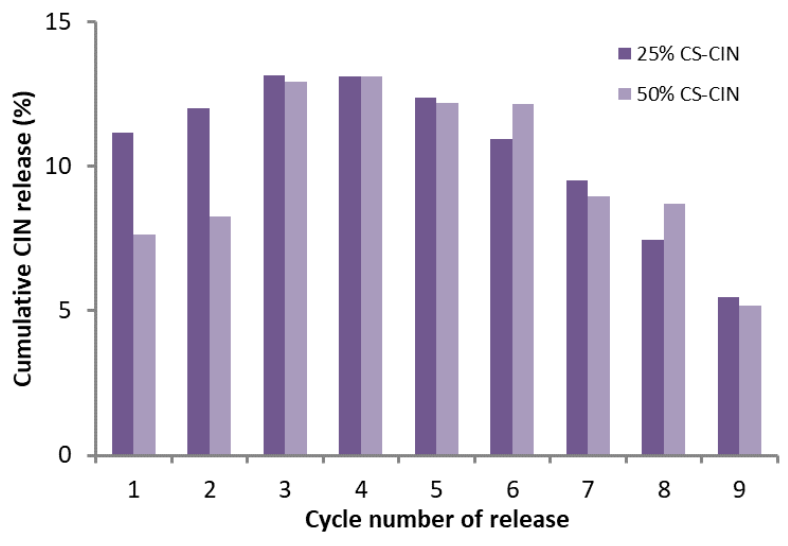

Fig. 11. Sustained release of CIN from CS-CIN microspheres

\section{CONCLUSION}

In this study, cinnamaldehyde (CIN) was successfully encapsulated in chitosan (CS) microspheres, and this result was demonstrated by FTIR and SEM analysis. The resulting CS-CIN microspheres were found to have a high $\mathrm{EE}$, and each 1 $\mathrm{g}$ of CS encapsulated a maximum of $350.06 \mathrm{mg}$ of CIN. A total of $95 \%$ of this encapsulated amount was released in PBS medium in a controlled manner. In addition, an in vitro release study of CIN was performed using CS-CIN microspheres, and sustained release of CIN was found to be possible in light of the results obtained from the studies presented here. The CIN, which was released from CS-CIN microspheres and reached a maximum concentration in PBS medium after 60 minutes, continued to be released from CS-CIN microspheres when the solution medium was completely changed. Therefore, it is obvious that this microsphere system will keep a constant amount of CIN in the environment and will continue to release CIN in order to stabilize the concentration when the amount of CIN in the environment decreases.

In addition, no crosslinking agent or surfactants were used during the preparation of CS microspheres. Both CS and CIN are from renewable resources, and there is a minimal use of reagents and a minimal amount of waste, which makes this method environmentally desirable. Therefore, CSCIN microspheres prepared in such a fashion have the potential to be used as a sustained release system in the food and medical industries, especially in tissue engineering applications.

Acknowledgement: This research has been supported by FDK-2015-539 COMU Scientific Research Project (BAP).

\section{REFERENCES}

[1] R. Jayakumar, M. Prabaharan, S. V. Nair, H. Tamura, Novel chitin and chitosan nanofibers in biomedical applications, Biotechnol. Adv. (2010).

DOI: https://doi.org/10.1016/j.biotechadv.2009.11.001.

[2] F. Casanova, B. N. Estevinho, L. Santos, Preliminary studies of rosmarinic acid microencapsulation with chitosan and modified chitosan for topical delivery, Powder Technol., 297, 44-9 (2016).

DOI: https://doi.org/10.1016/j.powtec.2016.04.014.

[3] L. Baldino, S. Cardea, I. De Marco, E. Reverchon, Chitosan scaffolds formation by a supercritical freeze extraction process, J. Supercrit Fluids, 90, 27-34 (2014). DOI: https://doi.org/10.1016/j.supflu.2014.03.002.

[4] U. Siripatrawan, W. Vitchayakitti, Improving functional properties of chitosan films to be used as active food packaging by incorporation with propolis, Food Hydrocoll, (2016).

DOI: https://doi.org/10.1016/j.foodhyd.2016.06.001.

[5] M. Z. Elsabee, H. F. Naguib, R. E. Morsi, Chitosan based nanofibers, review, Mater Sci. Eng. C, 2012. DOI: https://doi.org/10.1016/j.msec.2012.05.009.

[6] D. Archana, J. Dutta, P. K. Dutta, Evaluation of chitosan nano dressing for wound healing: characterization, in vitro and in vivo studies, Int. J. Biol. Macromol., 57, 193-203 (2013).

DOI: https://doi.org/10.1016/j.ijbiomac.2013.03.002. 
[7] X. Cai, H. Tong, X. Shen, W. Chen, J. Yan, J. Hu, Preparation and characterization of homogeneous chitosanpolylactic acid/hydroxyapatite nanocomposite for bone tissue engineering and evaluation of its mechanical properties, Acta Biomater., 5, 2693-703 (2009). DOI: https://doi.org/10.1016/j.actbio.2009.03.005.

[8] C. A. Cust Odio, M. T. Cerqueira, A. P. Marques, R. L. Reis, J. F. Mano, Cell selective chitosan microparticles as injectable cell carriers for tissue regeneration, Biomaterials, (2014).

DOI: https://doi.org/10.1016/j.biomaterials.2014.11.047.

[9] J. K. Suh, H. W. Matthew, Application of chitosan-based polysaccharide biomaterials in cartilage tissue engineering: A review, Biomaterials, 21, 2589-98 (2000).

[10] H. Sashiwa, S. I. Aiba, Chemically modified chitin and chitosan as biomaterials, Prog. Polym. Sci., 29, 887-908 (2004).

DOI: https://doi.org/10.1016/j.progpolymsci.2004.04.001.

[11] G. Li, L. Zhang, C. Wang, X. Zhao, C. Zhu, Y. Zheng, et al., Effect of silanization on chitosan porous scaffolds for peripheral nerve regeneration, Carbohydr. Polym., 101, 718-26 (2014).

DOI: https://doi.org/10.1016/j.carbpol.2013.09.064.

[12] J. Wang, L. Wang, H. Yu, A. Zain-ul, Y. Chen, Q. Chen, et al. Recent progress on synthesis, property and application of modified chitosan: An overview. Int. J. Biol. Macromol., 88, 333-44 (2016).

DOI: https://doi.org/10.1016/j.ijbiomac.2016.04.002.

[13] A. Bernkop-Schnürch, S. Dünnhaupt, Chitosan-based drug delivery systems, Eur. J. Pharm. Biopharm., 81, 463-9 (2012). DOI: https://doi.org/10.1016/j.ejpb.2012.04.007.

[14] B. Jung, P. Theato, Chitosan and chitosan derivatives in drug delivery and tissue engineering, Adv. Polym. Sci., 1-34 (2012). DOI: https://doi.org/10.1007/12.

[15] S. F. Hosseini, M. Zandi, M. Rezaei, F. Farahmandghavi, Two-step method for encapsulation of oregano essential oil in chitosan nanoparticles: preparation, characterization and in vitro release study, Carbohydr. Polym., 95, 50-6 (2013).

DOI: https://doi.org/10.1016/j.carbpol.2013.02.031.

[16] P. Suppakul, Cinnamaldehyde and Eugenol. Elsevier Inc., 2016. DOI: https://doi.org/10.1016/B978-0-12-800723-5.00039-5.

[17] P. A. Ponce Cevallos, M. P. Buera, B. E. Elizalde, Encapsulation of cinnamon and thyme essential oils components (cinnamaldehyde and thymol) in $\beta$ cyclodextrin: Effect of interactions with water on complex stability, J. Food Eng., 99, 70-5 (2010). DOI: https://doi.org/10.1016/j.jfoodeng.2010.01.039.

[18] Y. Sun, M. Zhang, B. Bhandari, B. Bai, Nanoemulsionbased edible coatings loaded with fennel essential oil/cinnamaldehyde: Characterization, antimicrobial property and advantages in pork meat patties application, Food Control, 127, 108151 (2021). DOI: https://doi.org/10.1016/j.foodcont.2021.108151.

[19] K. A. Rieger, J. D. Schiffman, Electrospinning an essential oil: cinnamaldehyde enhances the antimicrobial efficacy of chitosan/poly(ethylene oxide) nanofibers, Carbohydr. Polym., 113, 561-8 (2014). DOI: https://doi.org/10.1016/j.carbpol.2014.06.075.
[20] I. N. Ghosh, S. D. Patil, T. K. Sharma, S. K. Srivastava, R. Pathania, N. K. Navani, Synergistic action of cinnamaldehyde with silver nanoparticles against sporeforming bacteria: a case for judicious use of silver nanoparticles for antibacterial applications, Int. J. Nanomedicine, 8, 4721-4731 (2013). DOI: https://doi.org/10.2147/IJN.S49649.

[21] E. N. Faikoh, Y. H. Hong, S. Y. Hu, Liposomeencapsulated cinnamaldehyde enhances zebrafish (Danio rerio) immunity and survival when challenged with Vibrio vulnificus and Streptococcus agalactiae, Fish Shellfish Immunol, 2014. DOI: https://doi.org/10.1016/j.fsi.2014.02.024.

[22] B. Muhoza, S. Xia, J. Cai, X. Zhang, Duhoranimana E, $\mathrm{Su}$ J. Gelatin and pectin complex coacervates as carriers for cinnamaldehyde: Effect of pectin esterification degree on coacervate formation, and enhanced thermal stability, Food Hydrocoll, 2019.

DOI: https://doi.org/10.1016/j.foodhyd.2018.08.051.

[23] W. Chen, F. Cheng, C. J. Swing, S. Xia, X. Zhang, Modulation effect of core-wall ratio on the stability and antibacterial activity of cinnamaldehyde liposomes, Chem. Phys. Lipids, 2019. DOI: https://doi.org/10.1016/j.chemphyslip.2019.104790.

[24] Y. Kawamura, H. Yoshida, S. Asai, I. Kurahashi, H. Tanibe, Effects of chitosan concentration and precipitation bath concentration on the material properties of porous crosslinked chitosan beads, Sep. Sci. Technol., 32, 1959-74 (1997).

DOI: https://doi.org/10.1080/01496399708000748.

[25] T. Swaroopa Rani, S. R. Nadendla, K. Bardhan, J. Madhuprakash, A. R. Podile, Chitosan conjugates, microspheres, and nanoparticles with potential agrochemical activity, Agrochemical Detection, Treatment and Remediation (Pesticides and Chemical Fertilizers), 437-464 2020.

DOI: https://doi.org/10.1016/b978-0-08-103017-2.00017-9.

[26] P. Subhaswaraj, S. Barik, C. Macha, P. V. Chiranjeevi, B. Siddhardha, Anti quorum sensing and anti biofilm efficacy of cinnamaldehyde encapsulated chitosan nanoparticles against Pseudomonas aeruginosa PAO1. LWT, 97, 752-759 (2018). DOI: https://doi.org/10.1016/j.lwt.2018.08.011.

[27] K. I. Matshetshe, S. Parani, S. M. Manki, O. S. Oluwafemi, Preparation, characterization and in vitro release study of $\beta$-cyclodextrin/chitosan nanoparticles loaded Cinnamomum zeylanicum essential oil, Int. J. Biol. Macromol., 118, 676-82 (2018). DOI: https://doi.org/10.1016/j.ijbiomac.2018.06.125.

[28] A. Shetta, J. Kegere, W. Mamdouh, Comparative study of encapsulated peppermint and green tea essential oils in chitosan nanoparticles: Encapsulation, thermal stability, in-vitro release, antioxidant and antibacterial activities, Int. J. Biol. Macromol, 2019.

DOI: https://doi.org/10.1016/j.ijbiomac.2018.12.161.

[29] Siti Nur Ashakirin, Minaketan Tripathy, Umesh Kumar Patil ABAM. Chemistry and bioactivity of cinnamaldehyde: a natural molecule of medicinal importance, Int J. Pharm. Sci. Res., 8, 2333-40 (2017). DOI: https://doi.org/10.13040/IJPSR.0975-8232.8(6).233340. 
[30] A. I. Scott, Interpretation of the Ultraviolet Spectra of Natural Products (A volume in International Series of Monographs on Organic Chemistry), Pergamon, ISBN 9780080136158, (1964)

DOI:https://doi.org/10.1016/B978-0-08-0136158.50008-X.

[31] R. A. Mauricio-Sánchez, Salazar R, Luna-Bárcenas JG, Mendoza-Galván A. FTIR spectroscopy studies on the spontaneous neutralization of chitosan acetate films by moisture conditioning, Vib. Spectrosc., 2018.

DOI: https://doi.org/10.1016/j.vibspec.2017.10.005.

[32] K. V. Harish Prashanth, F. S. Kittur, R. N. Tharanathan, Solid state structure of chitosan prepared under different N-deacetylating conditions, Carbohydr. Polym., 50, 2733 (2002).

DOI: https://doi.org/10.1016/S0144-8617(01)00371-X.
[33] K. T. Trifković, N. Z. Milašinović, V. B. Djordjević, M. T. K. Krušić, Z. D. Knežević-Jugović, V. A. Nedović, et al., Chitosan microbeads for encapsulation of thyme (Thymus serpyllum L.) polyphenols, Carbohydr. Polym., 2014. DOI: https://doi.org/10.1016/j.carbpol.2014.05.053.

[34] M. Ji, X. Sun, X. Guo, W. Zhu, J. Wu, L. Chen, et al., Green synthesis, characterization and in vitro release of cinnamaldehyde/sodium alginate/chitosan nanoparticles, Food Hydrocoll, 90, 515-22 (2019). DOI: https://doi.org/10.1016/J.FOODHYD.2018.12.027.

[35] A. Loquercio, E. Castell-Perez, C. Gomes, R. G. Moreira, Preparation of Chitosan-Alginate Nanoparticles for Trans-cinnamaldehyde Entrapment, J. Food Sci., 80, N2305-15 (2015).

DOI: https://doi.org/10.1111/1750-3841.12997. 